ÇOMÜ Uluslararası Sosyal Bilimler Dergisi 4(1), 127-137, 2019

COMU International Journal of Social Sciences 4(1), 127-137, 2019

\title{
II. Dünya Savaşı Sırasında Franz Von Papen Suikastı Çerçevesinde Türkiye, Sovyetler Birliği ve Almanya ilişkileri
}

Başak KARATAŞ*

Öz

Franz Von Papen, Almanya'nın aslında Avrupa'da bir çatışmadan ve savaştan kaçınmak istediğine, Türkiye'yi inandırmakla görevlendirilmiş olarak 18 Nisan 1939 tarihinde Ankara Büyükelçisi olarak atandı. Bu dönemde Türkiye'nin dış politikasında en önemli problem italya'nın saldırgan tutumu idi; ancak Almanya'nın Batı Avrupa'da hızla ilerlemesi sonucu Türkiye 1940 yılının Mart ayından itibaren Almanya ile ilişkilerini daha sıcak kurmaya başladı ve 1941 yılı Haziran ayında da ittifak anlaşması imzaladı. Bu tarihten hemen sonra başlayan Almanya-Sovyetler Birliği savaşında kimin kazandığının belli olacağı 1944 yılının yaz aylarına kadar geçen süre içerisinde Türkiye'de yaşanan Papen suikast ve davası, Türkiye'nin II. Dünya Savaşı yıllarında uyguladığı dış politikasının, Güçlü Tarafa Meyleden Tarafsızlık siyaseti olduğunun örneklerinden biri olarak karşımıza çıkmaktadır.

Anahtar Kelimeler: Franz Von Papen, Suikast, Türkiye, Sovyetler Birliği, Almanya.

\section{Turkey, Soviet Uninon and Germany Realations within the frame of Franz von Papen Assasination during World War II}

\begin{abstract}
Turkey, Soviet Uninon and Germany Realations within the frame of Franz von Papen Assasination during World War II. Franz von Papen appointed as Ambassador of Germany in Ankara in $18^{\text {th }}$ April 1939 as commissioned to convince Turkey that Germany doesn't want any conflict or war in Europe. In these times, agressive attitude of Italy was the biggest problem of Turkish foreign policy. However, due to German progress at the Western Europe, Turkey got closer to Germany in March of 1940 and signed an alliance agreement with Germany in June of 1941. After this period, Germany-Soviet Union War begun. In the summer of 1944 when was going to be obvious who was going to win the war.During summer of 1944, Papen assasination and case in Turkey was the one of the examples of neutrality policy of Turkey which got closer to the powerful side during World War II.
\end{abstract}

Keywords: Franz von Papen, Assasination, Turkey, Soviet Union, Germany.

Öğretim Görevlisi, Çanakkale Onsekiz Mart Üniversitesi, Lapseki Meslek Yüksekolu, bilgekaratas10@gmail.com 


\section{GIRIŞ: II. DÜNYA SAVAŞI ÖNCESI TÜRKIYE'NIN DIŞ POLITIK DURUMU VE VON PAPEN'IN BÜYÜKELÇi OLARAK GÖREVLENDIRILMESi}

II. Dünya Savaşı başlamadan hemen önce Avrupa kıtası siyasi ve ideolojik olarak çalkantilı günlerin habercisi olacak siyasi olaylara sahne olmuştur. Savaş öncesi yaşanan söz konusu olaylar çalışmanın sınırlarını aşmakla birlikte kısaca bahsetmekte yarar vardır. Nitekim bir önceki dünya savaşının etkileri ile şekillenecek siyaset sahnesi, esasında yeni başlayacak tarihi silsilenin de tetikleyicisi niteliğindedir. Şöyle ki, I. Dünya Savaşı sonrası imzalanan Versailles Anlaşması hükümlerini tanımadığını belirterek, İngiltere ve Fransa ile boy ölçüşmek için İtalya'nın Faşist Lideri Benito Mussoloni ile anlaşan Adolf Hitler, 1936 yılında Berlin-Roma mihverini oluşturmayı başardı. Hitler, Germen kökenlilerin çoğunlukta oldukları yerleri kendi topraklarına katmaya yönelerek önce Avusturya'yı (1938), arkasından Çekoslavakya'yı (1939) Alman topraklarına katt. 1935'te Habeşistan'ı işgal eden Mussoloni de bu kez Arnavutluk'a saldırdı.

Alman Dışişleri Bakanı Ribbentrop, İtalya'nın Arnavutluk'u işgal ettiği 1939 yılının Nisan ayında, Franz Von Papen'i Ankara Büyükelçisi olarak atadı. Almanya'nın Propaganda Bakanı Goebbels, 12 Nisan günü Ankara'yı özel olarak ziyaret ederek, Papen'in atanması ile ilgili olarak temaslarda bulundu ve 14 Nisan'da Türkiye'den ayrıldı ${ }^{1}$. Papen'in Ankara Büyükelçiliği'ne resmi olarak atanması 18 Nisan'da gerçekleşti. İtalya'nın Arnavutluk'u işgali, Türkiye'de, Balkanlar'a ve dolayısı ile Türkiye'ye yönelik bir saldırganlık olabileceği endişesi doğurmuştu. Bu nedenle Papen, Almanya'nın aslında Avrupa'da bir çatışmadan ve savaştan kaçınmak istediğine, Türkiye'yi inandırmakla görevlendirilmişti. Papen, Balkan Devletleri'nin ve Türkiye'nin bir tehdit altında olmadığına ilişkin İtalya'dan inandırıcı bilgilerin olduğu gibi bir tutumla, Türkiye'yi Almanya'ya karşı olabilecek bir ittifak anlaşması imzalamasından alıkoymak amacında olacakt. İtalya'nın Arnavutluk'u işgalinden sonra, son derece hızlı gelişen Türk-İngiliz görüşmelerinin olumlu yönde sonuçlanmasını önlemek, bu sırada Alman dış politikasının ve dolayısıyla Papen'in temel amacı idi.

Papen, 26 Nisan 1939'da İstanbul'a ve bir gün sonra da Ankara'ya gelerek Şükrü Saraçoğlu ile görüştü. Papen bu görüşsmede, Mihver güçlerinin tüm sorunları barış̧̧ı bir şekilde çözme arzularını ve kendilerini çevreleme politikalarına karşı tüm güçleri ile ve kararlı biçimde karşı koyacaklarını bildirmişti. Papen'in bu açıklamalarına karşı Şaraçoğlu, Hitlerin, Almanya'nın kalkınması yolundaki çabalarını mucize olarak nitelendirerek, İtalya'nın Akdeniz'deki planlarına karşı Türkiye'nin duyduğu derin güvensizliği anlatmışt. Arnavutluk'un işgali, Türkiye için kendi topraklarının güvenliğini tehdit ediyordu. Çünkü Türkiye, Boğazlara olası bir saldırının sadece karadan, yani Balkanlar'dan yapılabileceğini biliyor ve bu nedenle de Balkanlar'ı kendi güvenlik bölgesi olarak görüyordu. Saraçoğlu, Türkiye'nin Almanya'ya karşı dostça görüşler taşıdığına ilişkin güvence vermişti. Papen de İtalya-Türkiye çatışmasına karşı, İtalya'nın Yunanistan'a karşı yaptığı gibi Türkiye'ye de bir garanti açıklaması yapması taraftarı olduğunu belirtti². Fakat İtalya'nın Balkanlar

1 Goebbels'in Ankara'dan ayrıldığı gün olan 14 Nisan'da bir Türk heyeti, Hitler'in 50. yaş gününü kutlamak üzere Almanya'ya giderek 20 Nisan'da Hitler ile görüşüp1 Mayıs'ta ülkeye döndüler. Bu heyet, Nafia Vekili Ali Fuat Cebesoy, Genelkurmay İkinci Başkanı Asım Gündüz, Akşam Gazetesi'nden Necmettin Sadak, Yeni Sabah Gazetesinden Hüseyin Cahit Yalçın, Ulus Gazetesi'nden Falih Rıfkı Atay ve Cumhuriyet Gazetesi'nden Nadir Nadi gibi önemli kişilerden oluşuyordu. Ayrıntılı bilgi için bkz. Cemil Koçak, Türkiye'de Milli Şef Dönemi, c. I, İletişim Yayınları, İstanbul 1996, s. 361. 
ve Akdeniz konusundaki görüşlerine karşı Türkiye'nin endişesi Papen'in önerdiği formülle ortadan kalkmayacak kadar büyüktü. Ankara'nın görüşü, Almanya'ya da İtalya, Balkanlar’a saldırmadığı sürece tarafsızlık politikasını korumak, aksi halde İngiltere'nin yanında tutum almakt.

18 Nisan 1939'da güven mektubunu sunan Papen, 29 Nisan'da da İnönü ile görüşmüştü. İtalya'nın Arnavutluk'a saldırısından ve Almanya-italya yakın işbirliğinden endişe duyduğunu vurgulayan İnönü'ye, Papen'in barışın korunacağına ilişkin verdiği güvence yeterli olmadı. İnönü, bu tür güvencelerin yeterli olmayacağını vurguladı ve sonuçları beklemeyi tercih edeceğini belirtti. ${ }^{3}$ İtalya'nın Arnavutluk'a saldırısı, Papen'i Ankara'da zor duruma düşürmüştü; fakat asıl amacı Türkiye'nin Batlı Devletlerle ittifak görüşmelerini dondurmak olan Papen, Berlin aracılı̆̆ı ile Mussoloni'den İtalya'nın askeri gücünü Arnavutluk'tan çekmesini ve bir iyi niyet ifadesi olarak Ege Denizi'nde Türk karasularına yakın olan iki adayı Türkiye'ye bırakmasını öneriyordu. Mussoloni bu öneriyi, bunun Türkiye'nin tutumunda değişiklik yapmayacağı görüşü ile reddetti ${ }^{4}$.

\section{TÜRKIYE-ALMANYA YAKINLAŞMASI VE VON PAPEN}

İtalya'nın Arnavutluk'u işgalinden hemen sonra başlayan Türkiye-İngiltere görüşmeleri ilerledi ve Ankara'nın tarafsızıı politikasının devamını sağlamaya çalışan Papen, 12 Mayıs 1939'da imzalanan Türk-İngiliz ortak deklarasyonuna engel olamadı. Ertesi gün Saraçoğlu ile görüşen Papen, İtalya tehdidinin yarattğı koşulların değişmesi ile bu deklarasyonun ittifak anlaşması yönünde ilerleme kaydetmeyeceği düşüncesini dile getirmişti. 15 Mayıs'ta bu amaçla Berlin'e giden Papen, Türkiye'nin Boğazlar ve Balkanlar'daki etkisinin yanı sıra, Ingiltere'nin Hindistan'a giden yolu olan Ortadoğu'da da etkili olabileceği, bu nedenle her nasıl olursa olsun Türkiye'nin en azından tarafsızığını koruması için İtalya'nın tutumunu değiştirmesi gerektiğini bildirmesine rağmen bu girişimi sonuçsuz kaldı. 22 Mayıs'ta imzalanan Almanya-Italya İttifak Anlaşması ile konu tamamen gündemden düştü. ${ }^{5}$

Almanya, Boğazların bekçisi olarak Türkiye'nin tarafsız kalmasını istiyordu. ${ }^{6}$ Türkiye'deki Alman Büyükelçisi Franz Von Papen, 14 Mart 1940 tarihinde İnönü ile görüşerek "silah zoruyla dahi olsa" Türkiye'nin tarafsızlığını korumasını istemişti.7 İnönü ise, Türkiye'nin Orta Avrupa'da güçlü ve bağımsız bir Almanya'ya ihtiyacı olduğunu, bu nedenle Almanya'nın durumunu zayıflatacak bir tutum olmayacağını belirtiyordu. ${ }^{8}$ Ankara, Akdeniz'de ne tam bir İngiliz ne de tam bir İtalya egemenliği istiyordu. Balkanlar'ın durumu ise, Balkan Pakt'nı etkileyecek ve Türkiye'yi tehlikeye sokacak duruma göre değişiklik gösterebilirdi.

3 Cemil Koçak, a.g.e., s. 374.

4 Ed. Baskın Oran, Türk Dış Politikası, c. I, İletişim Yayınları, İstanbul 2001, s. 387-388

5 Fahir Armaoğlu, a.g.e., s. 356.

6 SSCB Dışişleri Bakanlığı Almanya Dışişleri Bakanlığı Belgeleri, II. Dünya Savaşı'nda Türkiye Üzerinde Gizli Pazarlıklar (1939-1944), Örgün Yayınevi, İstanbul 2003, s. 262-264.

7 Selim Deringil, Denge Oyunu, İkinci Dünya Savaşı'nda Türkiye'nin Dış Politikası, Tarih Vakfi Yurt Yayınları, 3. Baskı, İstanbul 2003, s. 100. Basın ise bu dönemde Almanya'nın Türkiye'yi neden bîtaraf tutmak istediği izaha çalışılmıştır. Türkiye'ye karşı kesin tutumunun nasıl olduğu bilinmeyen bu dönemde Almanya'nın, bîtaraf tutarak ileride olası bir tecavüze karşı Türkiye'yi hazırlıksız yakalamak amacında olduğu ileri sürülmüştür. Bkz. "Bîtaraf Kurbanlar", Cumhuriyet, 11.5.1940.

8 Şerafettin Turan, İsmet İnönü, Yaşamı, Dönemi ve Kişiliği, T.C. Kültür Bakanlığı Yayınları, Ankara 2000, s. 244; Cemil Koçak, a.g.e., s. 399-400. 
1 Eylül 1939 tarihinde Almanya'nın Polonya topraklarına girerek Polonya'nın ani bir biçimde Almanya'ya yenilmesi, bütün dünyada olduğu gibi Türkiye'de de şaşkınlık yaratt. Almanya'nın Danimarka, Norveç, Hollanda ve Lüksenburg'u ele geçirdikten sonra, Fransa'ya karşı üst üste başarılar kazanması dünya politikasını Almanya'nın lehine çevirdi. Hatta İnönü, savaşın başlangıcından beri ilk defa 24 Mayıs 1940'da, tarafsız devletlerle birlikte Alman Büyükelçiliği onuruna davet verdi. ${ }^{9}$ Fakat yine de Türkiye, İtalya tehdidine karşı temkinli davranıyor, Balkanlar ve Akdeniz' in tehdit edilmesi durumunda savaşa katllacağını belirtiyordu. Almanya'nın 3 Temmuz'da, Fransa'dan ele geçirdiği bazı gizli belgeleri açıklaması, Türk-Sovyet ilişkilerini gerginleştirdi. Türkiye'yi yakından ilgilendiren Bakü Planı ile ilgili belgeler, Türkiye'yi hem Almanya'ya hem de Sovyetlere karşı uzaklaştırdı. ${ }^{10}$ Türkiye'nin, Alman ordusunun Bulgaristan'a girmesi ve Yunanistan'ı tehdit etmesi durumunda savaşa katılacağını bildirmesi üzerine, Berlin Ankara'nın Sofya'ya savaş ilan etmesi halinde Berlin'e de savaş ilan etmiş olacağını bildirdi. Bu karşılıklı restleşme, Türk-Alman ilişkilerini gergin hale soktu. 1940 yılı sonlarında başlayan Bulgaristan-Türkiye görüşmeleri sonucu, iki ülke arasında saldırmazlık anlaşması imzalandı. Böylece Türkiye, İngiltere tarafindan pek de hoş karşılanmasa da Almanya'ya karşı güvenliğini sağlamış oldu.

Rusya ise, Almanya'nın Balkanlar'daki politikasından rahatsız olmaya başlamışt. Bu nedenle Türk-Sovyet görüşmeleri sıcaklık kazandı. İngiltere, Türk-Sovyet görüşmelerini endişe ile izliyordu. Çünkü İngiltere, Saraçoğlu'nun Moskova ile yapacağı bir anlaşma sonucunda Türkiye'nin savaşa gireceği ve Akdeniz'de çıkacak bir savaş durumunda Batı'ya boğazları kapatabileceği görüşünde idi. Bu durumda, Ankara'nın Moskova ile anlaşarak Mihver Devletleri'ne yakınlaşması olasılığı karşısında, Türkiye, İngiltere ve Fransa arasında hazırlanmakta olan ittifak anlaşmasının tamamen suya düşmesi ihtimali bile mümkündü. TürkiyeRusya yakınlaşmasına neden olan bu gelişsmeler sayesinde, 1941 Martında Türk-Sovyet Deklarasyonu imzalandı. ${ }^{11}$ Böylece Türkiye, daha geniş bir hareket imkanı yakalamış oluyordu.

Almanya-Türkiye ilişkileri, Irak'ta Raşit Ali Geylani'nin, Almanya yanlısı bir yönetimi ele geçirmesinin ardından tekrar sıcaklık kazandı. Almanya, Türkiye üzerinden Irak’a yardım göndermek istemektedir. Bu istek, kısmen kabul edilmiş olsa da İngiltere, Geylani'yi devirerek Ortadoğu'ya hakim olunca, uygulanmadı. Bunun ardından, Türkiye'nin kendisini tehdit edecek Almanya ve İtalya çekincesi nedeni ile 18 Haziran 1941'de Türkiye-Almanya Dostluk ve Saldırmazlık Anlaşması imzalandı. ${ }^{12}$ Bununla taraflar, ülkelerinin toprak bütünlüğüne ve dokunulmazlığına saygı göstermeye ve birbirlerine karşı her türlü hareketten kaçınmaya söz veriyorlardı. Anlaşmanın önemli özelliği, her iki tarafin da var olan yükümlülüklerini, saklı tutması idi. ${ }^{13}$ Bu ilke, Türkiye'nin öteki devletlerle, özellikle İngiltere ve Fransa ile imzalamış olduğu ittifak anlaşması yönünden önemli idi. İngiltere ve ABD’nin bu anlaşmaya karşı Türkiye'yi haklı ve haksız görülmekte ihtilaf olması bir yana, Türkiye açısından bu anlaşma, Mihver Devletleri tarafinda savaşa katılma zorunluluğunu taşımaması nedeni ile kendisini daha rahat bir siyasi ortama taşımasını sağlamışt. Kısa zaman sonra, Alman ordularının

9 Fahir Armaoğlu, a.g.e., s. 366-368; Cemil Koçak, a.g.e., s. 495.

10 Ayrıntılı bilgi için bkz. Baskın Oran, a.g.e., s. 427-428.

11 Cemil Koçak, a.g.e., s. 266; 524-536.

12 Gece yarısı Dışişleri Bakanlığı'nda imzalanan anlaşma metnine Von Papen'in protokol metnine Almanya'nın Türkiye üzerinden harp malzemesi geçişini talep etmesi konusunda bkz. Nurettin Gülmez, Ersin Demirci, "Von Papen'in Türkiye Büyükelçiliği” Çağdaş Türkiye Tarihi Araştırmaları Dergisi, Cilt 13, Sayı 27, Ankara 2013, s.239 (ss. 225-250)

13 Fahir Armaoğlu, a.g.e., s. 410; Şerafettin Turan, a.g.e., s. 244. 
22 Haziran 1941 sabahı, Polonya toprakları üzerinden Alman-Sovyet sınırını geçerek genel bir saldırı başlatmaları ve Almanya ile Sovyetler arasında savaşın başladığı haberi, Türkiye üzerinden büyük bir yükü kaldırdı. Türkiye, o zamana kadar kendi üzerinde yapılmış bir pazarlık sonucunda oluşmuş, olası bir Alman-Sovyet işbirliği ve anlaşmasından her zaman kuşku duymuştu. Alman saldırısından kısa bir süre sonra Türkiye, bu savaşta tarafsız kalacağını açıklamasına rağmen, Almanya, Türkiye'nin savaşa katılması için baskı uygulamaya başladı. Bunun için Alman propaganda araçları Ankara'da daha etkin hale getirildi ve Alman ordularının Sovyet toprakları üzerindeki askeri başarıları, Türk basınında daha fazla yer aldı. Fakat Ankara, yine de siyasal rengini belli etmemeye gayret ediyordu. İktidarın kamuoyuna karşı yürüttüğü bu tavrı tam da "Inönü’nün II. Dünya Savaşı esnasındaki tarafsızlığı” ile ilgili genel kanıyı delilleyen bir tutum sergilediğine dair ipucu olabilir. Zira bilindiği üzere, "savaş süresince iktidarın taraf ya da tarafsızlık siyaseti" tartş̧maları özelikle savaş sonrasında Türk Dış Politikası'nın şekillenmesinde gündemi bir hayli meşgul etmiştir.

\section{VON PAPEN'E YAPILAN SUIKAST GIRIŞiMi VE ETKILERi}

Papen ve eşi, Türkiye'yi, Almanya safinda savaşa sokma çabalarına devam ederken, 24 Şubat 1942 sabahı, saat onu on dakika geçerken Ankara'nın Emniyet meydanı ile Kavaklıdere arasında Atatürk bulvarı üzerinde, Alman Büyükelçiliği önünde, bir bombanın patlaması sonucu yere yuvarlandı. İkisi de yara almadan kurtulurken arkalarında olan ve oradan geçmekte olan iki genç kız bombanın etkisi ile yaralandı. Bombanın, Alman büyükelçisi ile eşinin yakınında patlamış olması, bu suikastın büyükelçinin şahsına yönelik olması ihtimali üzerinde ciddi surette durmaya sevk ediyordu. Olaydan hemen sonra Dahiliye Vekili Faik Özttrak, Ankara Valisi Nevzat Tandoğan, Hariciye Vekili Şükrü Saraçoğlu ve CHP Genel Sekreteri Numan Menemencioğlu Ankara Büyükelçiliği'ne geldiler. Olay mahallinde yapılan araştırmalar sonucunda suikastçının bombayı atarken bombanın elinde patlaması sonucunda parçalanarak öldüğü saptandı. ${ }^{14}$ Olay ile ilgili resmi açıklama ise ancak 5 Mart 1942 tarihinde yapılacaktr:

"Resmi tebliğ: 24/2/1942 Salı günü Atatürk Bulvarı'nda vaki olan infilak hakkında zabıta tahkikatının bugüne kadarki neticeleri aşağıdadır:

1- İnfilak maddesini taşıyan ve bunu ateşleyen adam, aslen Üsküp vilayetinin Geylan kazasının Dobrean köyünden olup Üsküp’te tahsilini bitirdiğine dair diplomasi vardır. Yanında numarası silinmiş bir de tabanca taşımakta idi. Üsküp'te komünist olduktan sonra 5/10/1940 tarihinde yurdumuza gelmiş, ecnebi olarak İstanbul hukuk fakültesine kaydolmuş ve 9/5/1941 tarihinde muhacirler hakkındaki umumi hükümlerden istifade ederek vatandaşlığımıza girmiştir. Adı Ömer Tokat'tır. Üsküp'te muallim Halit Isic'in oğludur. Memleketindeki adi Omer Halidoviç Isiç'tir-1917 doğumludur.

2- İnfilâk neticesinde parçalanan bu adamını yakın arkadaşlarının hüviyetleri iki gün zarfinda tespit edilmiş ve arkadaşları yakalanmışlardır. Bunlar da Yugoslavya'da doğmuş, büyümüş, oralarda komünist olmuş ve son senelerde muhacir sıfatyla yurdumuza gelip vatandaşlığımıza girmiş kimselerdir.

3- Yakalanan suç ortaklarının ifadelerine göre, Ankara ve İstanbul'da hüviyetleri tespit edilen bazı ecnebilerin bunları yabancı bir devlete mensup iki zata karşı suikasta hazırladıkları öğrenilmiştir. Bu ecnebiler hakkında da tahkikat yapılmaktadır.

14 Tan Gazetesi, 25.02.1942; Ulus Gazetesi, 25.02.1942. 
4- Ankara'daki suikastın Almanya büyükelçisi Von Papen’e müteveccih olduğu anlaşımaktadır.

5- Tahkikata devam olunmaktadır." 15

Ömer Tokat'ın suç ortakları olarak Abdurrahman Sayman ile Süleyman Sav adında iki Türk ve Pavlof ve Kornilof adında Sovyetler Birliği'nin İstanbul Başkonsolosluğu'nda görevli iki vatandaşı da tutuklandı. Türk vatandaşları olan Sayman ve Sav da tıpkı olay mahallinde parçalanan Ömer Tokat gibi Üsküplü ve Yugoslavya'dan Türkiye'ye gelmişlerdi. Papen 7 Mart tarihli raporunda, bir Sovyet vatandaşının 6 Mart'ta Kayseri'de yakalandığını, diğerinin ise Sovyetler Birliği İstanbul Başkonsolosluğu'nda alıkonulduğunu belirterek Sovyet vatandaşı olan sanıkların, Sovyet gizli istihbarat örgütü GPU'nun (sonradan KGB) görevli elemanları olduğunun kesinlikle saptandığını; diğer yandan Türk hükümeti, saldırganların yakalanması için çok çaba harcarken, kamuoyu da bu olayda Almanya'nın yanında olduğunu"16 belirtiyordu. Ayrıca suikastın doğurduğu ortam Papen'e, Alman propaganda araçlarını kuvvetlendirme olanağı tanıdı. Muhtemelen bu amaçla, 2 Mart 1942 tarihinde, Ankara Valisi Nevzat Tandoğan aracılığı ile Ankara şehrinin muhtaçlarına 1.000 liralık bir çek verdiği görülmektedir. ${ }^{17}$

Papen suikastı davası, 1 Nisan'da başlamıştır. 1 Nisan'daki oturumda, Abdurrahman Sayman, aslen Üsküp'lü 1917 doğumlu ve babasının adının Ragıp olduğunu, 1938'de Türkiye'ye gelerek Türk tabiiyetine geçtiğini, İstanbul'da Tıp Fakültesi'ne devam ettiğini söyledi. Adem oğlu Süleyman Sav ise, 1908 doğumlu olduğunu, üç yıl önce Türkiye'ye gelerek Türk tabiyyetine girdiğini, Ankara'da Lozan Meydanı'nda, Lozan Apartmanı'nda ikamet ve Yenişehir'de Güneş Berber Salonu'nda kalfalık ettiğini bildirdi. Kornilof, 1908 doğumlu ve Sovyet Rusya tabiyyetinde olduğunu 1940 yılı Mayıs ayından beri Türkiye'de olduğunu söyledi. Pavlof, 1898 doğumlu ve Sovyet Rusya tebaası olduğunu ve halen İstanbul Sovyet konsoloshanesinde memur olduğunu bildirdi. Sorgusuna başlanan ilk olarak Abdurrahman Sayman oldu. Sayman suükast suçunu itiraf etmekle birlikte hakimin "Suikastın gayesi ne idi?" sorusuna, "Suikast düşüncesinin gayesi, Almanya ile Türkiye'nin arasını açıp bu suretle Rusların lehine harbe girmesini temin etmek olabilir" dedi ${ }^{18}$. Pavlof ise, Sayman ve Sav hakkında "Bunlar kendilerini Yugoslav komünisti olarak göstermektedirler. Hakikatte Türkiye ile Sovyet Rusya arasındaki münasebetleri bozmak için tahrik edilmişlerdir." diyerek, ikisini de tanımadıklarını söyledi. 8 Nisan 1942 tarihine duruşma ertelendi. ${ }^{19}$

Ömer Tokat'ın Ankara'da bulunduğu süre boyunca Toros Oteli'nde kaldığı iddiası ile Toros Oteli sahibi Bekir Seyfettin Sarığlu ile müstahdem Halit ve kapıcı Ali Çelik'in ifadelerine göre, Ömer Tokat 23 gün bu otelde konaklamışt. Bu kişilerin suikast sonrası Ömer Tokat'ın kimliğinin belirlenmesinde faydaları olmuştu. ${ }^{20}$ Bu arada suikast konusunun Sovyetler Birliği ve Almanya arasında da gerginlik yarattğı görülüyordu. Sovyet Rusya, bu suikastın Türkiye'nin komşuları ile arasını bozmak için Almanya tarafindan tertip edildiğini

15 Tan Gazetesi, 06.03.1942. Ayrıca bkz. Cumhuriyet Gazetesi, 06.03.1942, Ulus Gazetesi, 06.03.1942 İkdam Gazetesi 06.03.1942.

16 Cemil Koçak, a.g.e., s. 619.

17 Ulus Gazetesi, 03.03.1942.

18 Tan Gazetesi, 02.04.1942; Ulus Gazetesi,02.04.1942.

19 Tan Gazetesi, 02.04.1942.

20 Tan Gazetesi, 07.04.1942. 
iddia ediyor, ${ }^{21}$ Almanya ise bunu reddederek, davanın gidişinin şimdiden suikast büyük oranda aydınlattı̆ını ve suikastta Sovyet Rusya'nın parmağı olduğunu savunuyordu. ${ }^{22}$

8 Nisan 1942 tarihinde yapılan duruşmada. ${ }^{23}$ Pavlof, Abdurrahman'ın iddialarını çürütmek için, onun komünist olmadığını ileri sürecek açıklamalarda bulundu. Pavlof, kendisine gelen tebligatların Türkçe oluşu nedeni ile imza atmadığını ve hapishanedeki tercümanlara da güvenmediği için kendisine bir tercüman tahsis edilmesi gerektiğini de bildirdi. Hakim ise, Türkçe tebligatları noter aracılığı ile tespit edebileceğini bildirerek bu kadar evhama kapılmaması gerektiğini söyledi. ${ }^{24}$ Kornilof ise, "Ben bu güne kadar mahkemenin hakkaniyet ve adalet hilafina hareket ettiği hususunda hiçbir şey müşahade etmiş değilim" dedi. ${ }^{25}$ Bu duruşmada Ömer Tokat'tan arda kalan bazı parçaların duruşma salonuna getirilmesi, bu duruşmaya damgasını vurdu. 20 Mayıs'taki davada ise hakim:

"Türkiye ile Almanya arasındaki ananevî dostluğu belirten müddeiumumi, câniyane arzularla Almanya'nın Ankara büyük elçisi Von Papen'e yapılmak istenen ve büyük bir şans eseri olarak muvaffak olmayan bu suikast failin şu beş sebep yönünden tahakkuk ettiremediğini söylemiştir:

\section{1- Ömer, hayatını muhafaza etmek için bir an tereddüt etmiş olabilir.}

2-Von Papen'i gördüğü zaman ruhî durumu altüst olduğundan mesafeyi iyi tahmin edememiş olabilir.

\section{3- Infilak maddesinin patlaması anında herhangi bir aksilik vukua gelmiş, olabilir,}

\section{4- Infilâk kuvveti tahmin edilmeyebilir.}

5- Fail, o anda oradan geçmekte olan genç kızların hayatını bir an için muhafaza etmek isteyebilir ve aradan geçen sekiz saniyelik bir tereddüt anı da suikast meselesinin tahakkuk etmemesine yardım edebilir."26 demiştir.

Dava basında büyük ilgi ile karşılanırken nihayet 17 Haziran'da, Sovyet vatandaşı sanıklar yirmişer yıl, Türk vatandaşı sanıklar ise onar yıl hapis cezasına çarptırıldı. Bu kararın 16 Ekim 1942'de temyizce bozulması üzerine, yeni duruşma 4 Kasım'da yapıldı. Bu sefer Sav, Kornilof'un iddialarına katlarak Ömer Tokat'ın ölmediğini ve suikasttan sonra onu Ankara'da gördüğünü açıkladı. Sav, kendisine tercüman verildiği takdirde olayın gerçek yüzünü açıklayacağını söyledi; fakat mahkeme iddiaların gerçeğe uymadığı gerekçesi ile 23 Aralık'ta Pavlof ve Kornilof'a on altş̧ar yıl, Sav ile Sayman'a da onar yıl hapis cezası vererek davayı tekrar kapatt. Ancak bir buçuk yıl kadar sonra, Türkiye'nin Almanya ile ilişkilerini kestiği 2 Ağustos 1944 tarihinde tekrar gündeme gelen Papen suikast davasın-

21 Papen suikastının bir Nazi provakasyonu olduğu yönündeki değerlendirmeler ve detaylı bilgi için bkz. Sevtap Sırakaya, "Von Papen Suikastinde Sovyet İzleri ve Sovyet Basınının Tutumu", Ankara Üniversitesi Dil ve Tarih-Coğrafya Fakültesi Tarih Bölümü Tarih Araştırmaları Dergisi, C/S. 33 (55) Ankara 2014, ss. 379-392.

22 Tan Gazetesi, 08.04.1942.

23 Bugün şahitliği dinlenecek olanlar, Kamil kızı ve Mithat Kuruner'in eşi Mefharet Kuruner, Doktor Servet Kamil kızı Bigüm Tokgöz, Şöfor Ömer oğlu Ahmet Fahri Uçar, Ömer oğlu Adil Kanmaz, Nuri oğlu Bekir Seyfettin Marsoğlu, Mehmet Ali oğlu Halit Ünsal, Rıfat oğlu Ali Çelik, Hüseyin oğlu Kazım Özdemir, Asım oğlu Maruf Konurkaya, Ahmet Recep kızı Gülizar Gökçek, Mümin oğlu Ahmet Kalın, Josef oğlu Edward Romanski ve Yunus oğlu İsmail Korkulu idi. Bkz. Ulus Gazetesi, 04.04.1942.

24 Tan Gazetesi, 09.04.1942; Ulus Gazetesi, 09.04.1942,.

25 Ulus Gazetesi, 09.04.1942,

26 Tan Gazetesi, 21.05.1942. 
da, 9 Ağustos 1944 tarihinde yapılan duruşma ile sanıklar suçsuz bulunarak serbest bırakılacakt. ${ }^{27}$ Sanıkların serbest bırakılması noktasında da, Almanya'nın artık savaştan galip çıkamayacağına dair Türkiye'ye gelen istihbarat raporlarının etkili olduğu söylenebilir. Nitekim savaş sonrasında Türk dış politikasının hangi tarafa doğru bir seyir izleyeceğine dair, ikircikli diyebileceğimiz, fikir karmaşası yaşanması ve böyle sıcak bir atmosferde İsmet İnönü’nün SSCB ile zıtlaşmak istemediği anlaşılmaktadır.

\section{SONUÇ}

II. Dünya Savaşı boyunca, Türkiye'nin dış siyasasını doğrudan yöneten Cumhurbaşkanı İsmet İnönü, savaşan tarafların hemen hemen hepsi ile anlaşma imzalayarak, Türkiye'ye yönelik bir tehditten geri kalınmasını sağlayacak bir politika yürüttü. Her ne kadar Tarafsızlık teması üzerinden yürüse de Türkiye'nin dış politikası, II. Dünya Savaşı'nda Güçlü Taraf Meyleden Tarafsızlık ya da Denge Politikası biçimindeki ifadelere daha uygun görünmektedir. Neticede, II. Dünya Savaşı boyunca çeşitli çelişkilerden yararlanarak, kendisini savaşın dışında tutmayı amaçlayan Türkiye, dış politikasını dengede tutarak savaş dışı kalabildi. Özellikle İngiltere, Fransa, Sovyetler Birliği, Bulgaristan, Almanya gibi doğrudan savaşın içerisinde olan devletlerle yaptığı dostluk anlaşmaları ile güvenliğini sağladı. Türkiye, İtalya tehdidini Almanya üzerindeki politikası ile; Alman baskısını ise Sovyet tehdidi gerekçesi ile durdurmayı başardı. Müttefik Devletleri ise, Türkiye'nin savaşa girecek kadar güçlü olmadığı ve Alman tehdidini engelleyecek durumda olmadığı gerekçesi ile susturdu.

II. Dünya Savaşı esnasında Türkiye'yi en çok rahatlatan olay, müttefik şekilde yola çıkan iki devlet olarak Almanya ile Sovyetlerin savaşmaya başlaması olmuştur. Hemen yanı başında, Türkiye'ye tehlike yaratabilecek konumda olan Almanya ve Rusya'nın Türkiye üzerindeki emellerini harekete geçirmeleri çekincesi, Türkiye'yi hep rahatsız etmişti. Türkiye'nin çekingen tutumu, kendisini herhangi bir maceraya atımaktan alıkoyarken, aslında bu tutumun ne kadar doğru olduğu Almanya'nın Stalingrad yenilgisinden sonra anlaşılmıştr.

1942 yılında gerçekleşen Papen Suikast girişimi olayının hiçbir zaman tam olarak açıklığa kavuşmaması, her zaman olayın arkasındaki asıl nedenin ne olduğu konusunda çeşitli görüşlerin ileri sürülmesine neden oldu. Suikast hakkında Papen, Sovyet ajanlarının Türkiye'yi Sovyetler Birliği tarafinda savaşa katmak için bu suikastı yaptıklarını belirtmişse de suikast sonucu Almanya-Türkiye ilişkileri daha da sıkılaşmıştır. Papen suikastının somut etkisi, Türkiye-Sovyetler Birliği ilişkilerinin bozulması ve buna karşılık, Türk-Alman ilişkilerinde belirgin bir yakınlaşma şeklinde görülmüştür.

1942 yılında suikastın sanıkları 16'şar yıl hapis cezasına mahkum edilmişlerdi; ancak suikastın gerçekleşmesinin üzerinden bir buçuk yıl sonra, II. Dünya Savaşı́nın seyri değişmiş; Sovyetler Birliği, Almanya'yı püskürtmüştü. Nitekim Türkiye de 1944 yılının yaz aylarında, Almanya ile ilişkilerini kesti ve hemen bir hafta sonra yapılan duruşmada, Papen suikastı sanıklarının beraatına karar verildi. Tüm bunlara bakıldığında Papen suikast sürecinin, II. Dünya Savaşı yıllarında Türkiye'nin izlediği, Güçlü Tarafa Meyleden Tarafsızlık ya da Denge Politikası biçiminde ifade edilebilecek dış politik genel tavrına, önemli bir örnek olduğu görülmektedir.

27 Cengiz Atlı, "Türkiye'de II. Dünya Savaşı Sırasında İngiliz Alman Büyükelçileri'ne Suikast Girişimi, The Journal of Academic Social Science Studies, Number 28, Autumn 2014, p. 55-71. 


\section{KAYNAKÇA}

\section{Süreli Yayınlar}

Tan Gazetesi

Ulus Gazetesi

Cumhuriyet Gazetesi

İkdam Gazetesi

\section{Makale ve Kitaplar}

Armaoğlu, Fahir, 20. yy. Siyasi Tarihi, Alkım Yayınları, İstanbul, 2005.

Atlı, Cengiz, "Türkiye'de II. Dünya Savaşı Sırasında İngiliz Alman Büyükelçileri'ne Suikast Girişimi, The Journal of Academic Social Science Studies, Number 28, Autumn 2014, p. 55-71.

Deringil, Selim, Denge Oyunu, İkinci Dünya Savaşı'nda Türkiye'nin Dış Politikası, Tarih Vakfi Yurt Yayınları, 3. Baskı, İstanbul 2003.

Gülmez, Nurettin, Ersin Demirci, "Von Papen'in Türkiye Büyükelçiliği” Çağdaş Türkiye Tarihi Araştırmaları Dergisi, Cilt 13, Sayı 27, Ankara 2013, ss. 225-250.

Koçak, Cemil, Türkiye'de Milli Şef Dönemi, c. I, İletişim Yayınları, İstanbul 1996.

Oran, Baskın, Türk Dış Politikası, c. I, İletişim Yayınları, İstanbul 2001.

Sırakaya, Sevtap, "Von Papen Suikastinde Sovyet İzleri ve Sovyet Basınının Tutumu”, Ankara Üniversitesi Dil ve Tarih-Coğrafya Fakültesi Tarih Bölümü Tarih Araştrrmaları Dergisi, C/S. 33 (55) Ankara 2014, ss. 379-392.

SSCB Dışişleri Bakanlığı Almanya Dışişleri Bakanlığı Belgeleri, II. Dünya Savaşı’nda Türkiye Üzerinde Gizli Pazarlıklar (1939-1944), Örgün Yayınevi, İstanbul 2003.

Turan, Şerafettin, İsmet İnönü, Yaşamı, Dönemi ve Kişiliği, T.C. Kültür Bakanlığı Yayınları, Ankara 2000. 


\section{EKLER:}

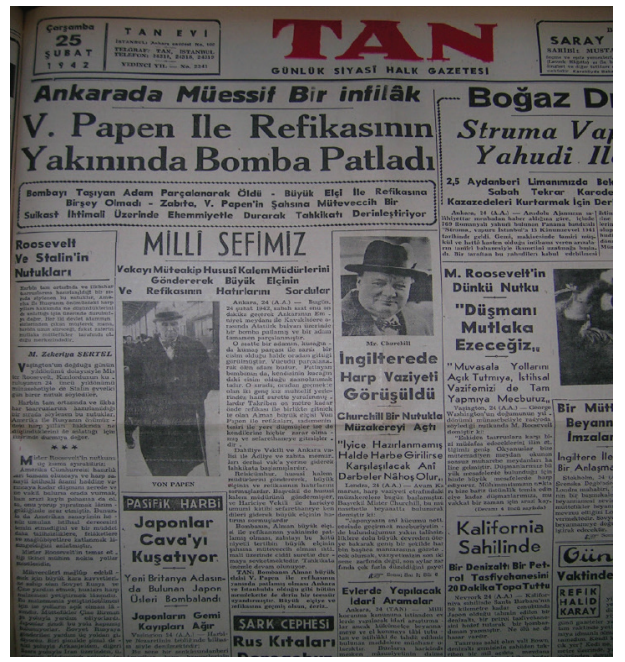

25 Şubat 1942 Tarihli Tan Gazetesi

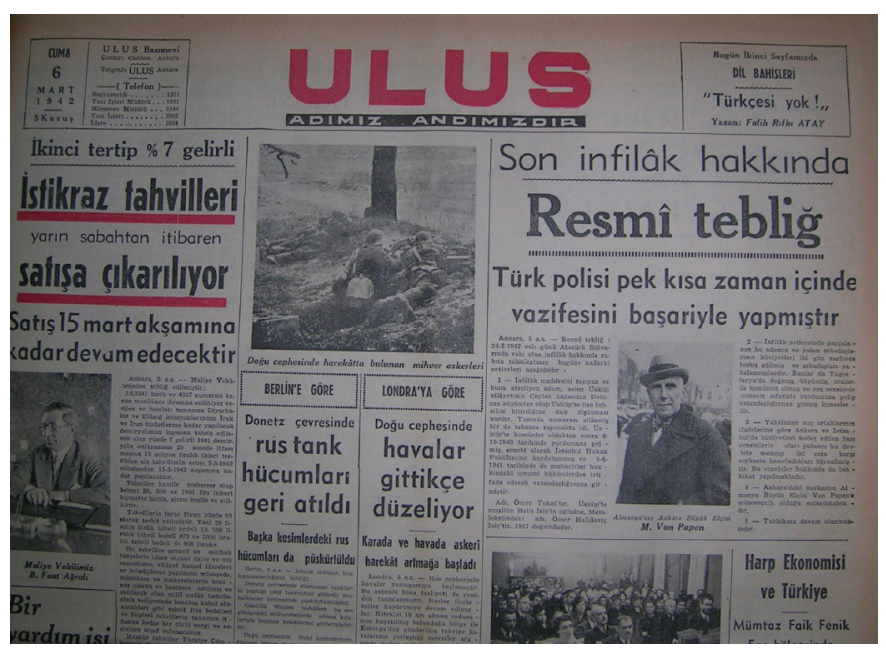

6 Mart 1942 Tarihli Ulus Gazetesi 


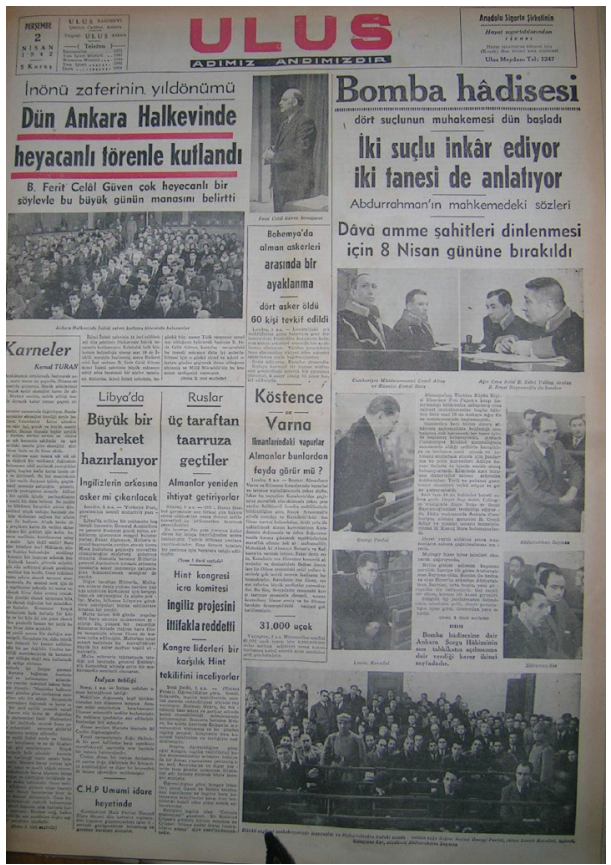

2 Nisan 1942 Tarihli Ulus Gazetesi

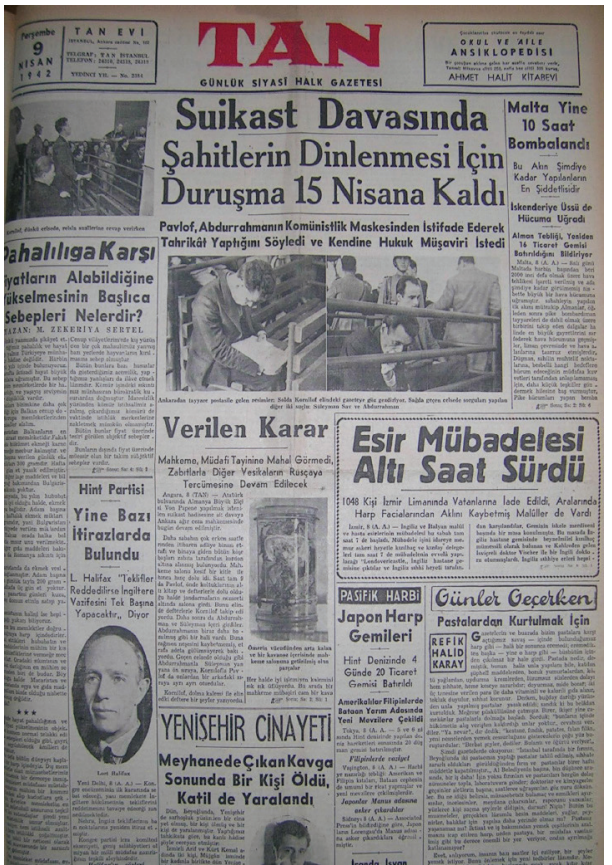

9 Nisan 1942 Tarihli Tan Gazetesi

II. Dünya Savaşı Sırasında Franz Von Papen Suikast Çerçevesinde Türkiye, Sovyetler Birliği ve 